\title{
Erratum to: Numerical damage prediction in dowel connections of wooden structures
}

\author{
M. Khelifa - A. Khennane - M. El Ganaoui • \\ A. Celzard
}

Published online: 22 July 2015

(C) RILEM 2015

\section{Erratum to: Materials and Structures DOI 10.1617/s11527-015-0615-5}

The authors wish to notify the following error in the aforementioned article.

An error has been found in Eq. (28), which should be corrected as:

$\mathrm{M}_{\mathrm{y}, \mathrm{Rk}}=0.3 \times \mathrm{f}_{\mathrm{u}, \mathrm{k}} \times \mathrm{d}^{2.6}$

The online version of the original article can be found under doi:10.1617/s11527-015-0615-5.

M. Khelifa $(\bowtie)$

University of Lorraine, 27 rue Philippe Séguin,

88026 Epinal Cedex, France

e-mail: mourad.khelifa@univ-lorraine.fr

M. Khelifa · M. El Ganaoui

LERMAB, EA 4370, 27 rue Philippe Séguin,

88026 Epinal Cedex, France

A. Khennane

School of Engineering and Information Technology,

UNSW, Canberra, Australia

M. El Ganaoui

University of Lorraine, IUT de Longwy,

54400 Cosnes et Romain, France

\section{A. Celzard}

University of Lorraine, Institut Jean Lamour - UMR

CNRS 7198, 27 rue Philippe Séguin, CS 60036,

88026 Epinal Cedex, France where $M_{y, R k}$ is the fastener yield moment, $f_{u, k}$ is the characteristic tensile strength, and $\mathrm{d}$ is the bolt diameter. Because of this error, one result is wrong in Table 4 (see below), from where the authors claimed that the analytical procedure of EC 5 [1] leads to an $82.7 \%$ underestimation of the connection strength with respect to the experimental result.

For steel-timber connections using multiple fasteners subjected to a loading parallel to grain near the end of the timber member, the characteristic load-carrying capacity of fracture along the perimeter of the fastener area, which can be caused either by block shear failure or by plug shear failure, should read:

$\mathrm{F}_{\mathrm{bs}, \mathrm{Rk}}=\max \left\{\begin{array}{l}1.5 \times \mathrm{A}_{\text {net, } \mathrm{t}} \times \mathrm{f}_{\mathrm{t}, 0, \mathrm{k}} \\ 0.7 \times \mathrm{A}_{\text {net }, \mathrm{v}} \times \mathrm{f}_{\mathrm{v}, \mathrm{k}}\end{array}\right.$

where

$$
\begin{gathered}
\mathrm{A}_{\text {net, } \mathrm{t}}=\mathrm{L}_{\text {net, } \mathrm{t}} \times \mathrm{t}_{1}=\sum_{\mathrm{i}} \mathrm{L}_{\mathrm{t}, \mathrm{i}} \times \mathrm{t}_{1}=48 \times 75 \\
=3600 \mathrm{~mm}^{2} \\
\mathrm{~A}_{\text {net }, \mathrm{v}}=\mathrm{L}_{\text {net }, \mathrm{v}} \times \mathrm{t}_{1}=\sum_{\mathrm{i}} \mathrm{L}_{\mathrm{v}, \mathrm{i}} \times \mathrm{t}_{1} \\
=2 \times 490 \times 75=73500 \mathrm{~mm}^{2}
\end{gathered}
$$

$F_{b s, R k}$ is the characteristic block shear or plug shear capacity; $A_{\text {net, }}$ is the net cross-sectional area perpendicular to the grain; $A_{n e t, v}$ is the net shear area in the direction parallel to the grain; $\mathrm{L}_{n e t, t}$ is the net width of the cross-section perpendicular to the grain; $\mathrm{L}_{\text {net,v }}$ is the total net length of the shear fracture area; $t_{1}$ is the 
timber member thickness or penetration depth of the fastener; $f_{t, 0, k}$ is the characteristic tensile strength of the timber member; and $f_{v, k}$ is the characteristic shear strength of the timber member.

The wood used in this study was C35 class, for which $\mathrm{f}_{\mathrm{t}, 0, \mathrm{k}}=21 \mathrm{MPa}$ and $\mathrm{f}_{\mathrm{v}, \mathrm{k}}=3.4 \mathrm{MPa}$. Hence:

$\mathrm{F}_{\mathrm{bs}, \mathrm{Rk}}=\max \left\{\begin{array}{c}1.5 \times 3600 \times 21=113.4 \mathrm{kN} \\ 0.7 \times 73500 \times 3.4=174.93 \mathrm{kN}\end{array}\right.$

The characteristic block shear or plug shear capacity $\mathrm{F}_{\mathrm{v}, \mathrm{Rk}}$ of the connection according to EC5 [1] is therefore:

$\mathrm{F}_{\mathrm{v}, \mathrm{Rk}}=2 \times \mathrm{F}_{\mathrm{bs}, \mathrm{Rk}}=349.86 \mathrm{kN}$

Table 4 should therefore be corrected as below:

The authors would like to apologize to the readers for any inconvenience this may have caused. The authors are indebted to Dr. A.J.M. Leijten from Eindhoven University of Technology for having detected the error,
Table 4 Maximum loads and displacements recorded at failure

\begin{tabular}{lccr}
\hline & Experiment (Test \#3) & Analytical & FEM \\
\hline $\mathrm{v}(\mathrm{mm})$ & 8.5 & - & 8.6 \\
$\Delta \mathrm{v} / \mathrm{v}(\%)$ & - & - & 1.2 \\
$\mathrm{~F}(\mathrm{kN})$ & 369.4 & 349.86 & 354.4 \\
$\Delta \mathrm{F} / \mathrm{F}(\%)$ & - & 5.3 & 4.1 \\
\hline
\end{tabular}

and would like to thank him for fruitful discussions while redacting the present erratum.

\section{Reference}

1. Eurocode 5: Design of timber structures-part 1-1: general -common rules and rules for buildings. Brussels (2010) 